\title{
Foliar fertilization on the production of grafted dwarf cashew seedlings
}

\author{
Adubação foliar na produção de mudas de cajueiro-anão
}

\author{
Ricardo Miranda dos Santos ${ }^{1}$ (D), Luiz Augusto Lopes Serrano ${ }^{2 *}$ (D) , Carlos Alberto Kenji Taniguchi (D), \\ Adriana Guirado Artur $^{1}$ (iD), William Natale ${ }^{3}$ (D), Márcio Cleber de Medeiros Corrêa ${ }^{3}$ (i)
}

\author{
'Universidade Federal do Ceará, Departamento de Ciências do Solo, Fortaleza, CE, Brasil \\ Embrapa Agroindústria Tropical, Empresa Brasileira de Pesquisa Agropecuária/Embrapa, Fortaleza, CE, Brasil \\ ${ }^{3}$ Universidade Federal do Ceará, Departamento de Fitotecnia, Fortaleza, CE, Brasil \\ *Corresponding author: luiz.serrano@embrapa.br \\ Received in November 20, 2019 and approved in December 23, 2019
}

\begin{abstract}
Foliar fertilization is an important agricultural technique that has stood out for its ease of use and can contribute to the production of high-quality and -vigor cashew seedlings. The objective of this study was to evaluate the effect of foliar fertilizer rates and time of application on 'BRS 226' dwarf cashew seedlings after grafting. The experiment was carried out in a completely randomized design, with five treatments and 24 replicates. Each experimental unit consisted of one plant. The commercial product (NPK 20-20-20) was used at the recommended rate for fruit crops in general, $2.5 \mathrm{~g} \mathrm{~L}^{-1}$. Foliar fertilizer applications at 45 and 60 days after grafting (DAG), with $50 \%$ of the recommended rate $\left(1.25 \mathrm{~g} \mathrm{~L}^{-1}\right)$, or at $80 \mathrm{DAG}$, with $100 \%$ of the recommended, promoted increments of $9 \%$ and $13 \%$ in the total dry mass, respectively, in comparison to unfertilized plants. Besides that, at 80 DAG the foliar fertilizer application caused significant difference in the B contents, allowed obtaining better quality 'BRS 226 ' grafted dwarf-cashew seedlings. In the production of grafted seedlings of 'BRS $226^{\prime}$ dwarf-cashew, it's recommended to foliar fertilization at 45 and 60 days after grafting, with $1.25 \mathrm{~g} \mathrm{~L}^{-1}$ of the product based on NPK 20-20-20; or a single dose application $2.5 \mathrm{~g} \mathrm{~L}^{-1}$ at 80 days after grafting.
\end{abstract}

Index terms: Anacardium occidentale; total dry matter; seedling quality; nutrient contents.

\section{RESUMO}

A adubação foliar é uma importante técnica agrícola que vem se destacando pela sua facilidade de utilização, podendo contribuir para a produção de mudas de cajueiro de alta qualidade e vigor. Objetivou-se com esse estudo avaliar doses e épocas de aplicação de adubo foliar em mudas de cajueiro-anão 'BRS 226 ' após a enxertia. O experimento foi conduzido em delineamento inteiramente casualizado, com cinco tratamentos e 24 repetições. Cada unidade experimental foi composta por uma planta. O produto comercial (NPK 20-20-20) foi utilizado na taxa recomendada para frutíferas em geral de 2,5 $\mathrm{g} \mathrm{L}^{-1}$. As aplicações do adubo foliar aos 45 e 60 dias após a enxertia, com $50 \%$ da dose recomendada e, 80 dias após a enxertia na dose recomendada promoveram incrementos de $9 \%$ e $13 \%$, respectivamente, em relação à testemunha. Além disso, aos 80 DAG, a aplicação de fertilizante foliar causou diferença significativa no conteúdo de $B$, permitindo obter mudas enxertadas de cajueiro-anão 'BRS 226 ' com melhor qualidade 'BRS 226'. Na produção de mudas enxertadas de cajueiro anão 'BRS 226', recomenda-se a fertilização foliar aos 45 e 60 dias após a enxertia, com 1,25 g L-1 do produto à base de NPK 20-20-20; ou aplicação de dose única $2,5 \mathrm{~g} \mathrm{~L}^{-1}$ aos 80 dias após o enxerto.

Termos para indexação: Anacardium occidentale; massa seca total; mudas de qualidade; teor de nutrientes.

\section{INTRODUCTION}

By 2019, 3.7 million tonnes of cashew nuts is expected worldwide and cashew (Anacardium occidentale L.) cultivation has economic and social importance for countries with warm and dry climates. West Africa has stood out in recent years with increasing productions from Ivory Coast, Nigeria, Benin, Ghana and Togo. On the east side, Mozambique and Tanzania stand out and in Asia there are the traditional countries in both exportation and importation of cashew nuts, India and Vietnam. Brazil is the center of origin for cashew trees, and after being one of the world's leading producers until the 1980s, it is currently the 7 th largest producer in the world $(140,000$ tonnes per year on 430,000 hectares). Yield in Brazil has decreased, the main cause being the great heterogeneity of the orchards, which were formed by non-grafted plants (seminal), besides the low use of technologies for their cultivation. An alternative to avoid this problem is planting 
orchards with grafted seedlings (clonal), which in addition to standardizing the growth and yield of plants, causes the production to start earlier (Mesquita et al., 2010; Cavalcanti Júnior, 2013). This recovery of orchards through the use of clonal plants (grafted seedlings) has also been carried out by the producing countries of the African and Asian continents. Seedling quality is the most important item to be considered at the planting of an orchard, as the seedlings must tolerate environmental adversities after planting, such as high temperatures, water stress and phytosanitary problems. For this, it is necessary to use a substrate with the ability to retain water and provide it for plants, good porosity to facilitate the oxygenation of seedling roots, good consistency (Calvacanti Júnior, 2013) and, mainly, the capacity to provide nutrients according to the demand during seedling development.

Fertilization of dwarf-cashew seedlings is not yet a widely used practice, and research studies are needed to define sources, rates and time of application. The use of foliar fertilization may be an option, as an agricultural technique for supplying the nutrients necessary for the development of seedlings in the nursery stage.

Foliar fertilization, due to the direct application on the leaves, favors greater absorption of macro- and micronutrients by plants, compared to soil fertilization. In addition, lower rates are applied, promoting immediate responses in plants, facilitating corrections of possible nutritional deficiencies (Esashika; Oliveira; Moreira, 2011), being a means of compensating the deficiencies in the soil or substrate (Sullivan et al., 2014; Patil; Chetan, 2018).

Foliar fertilization can be performed according to the specific requirements in each development stage of the crop, besides stimulating the root system to absorb nutrients from the soil solution (Fernández; Eichert, 2009). Another advantage over soil application of fertilizer is that there is no dependence on soil moisture and $\mathrm{pH}$, as well as other chemical and physical properties for nutrient absorption (Kostadinov; Kostadinova, 2014). At the same time, foliar application contributes to reducing soil chemical contamination (Haytova, 2013).

The main factors which may affect foliar fertilization effectiveness are related to the absorption rate and the mobility of each nutrient within plant tissues and organs (Fernández; Sotiropoulos; Brown, 2013). In addition, an adhesion agent and good leaf area are required for higher efficiency, and foliar fertilizers are subject to climatic factors and can cause injuries if applied at high concentrations (Patil; Chetan, 2018). The response to foliar fertilization is often variable and not reproducible, so knowledge is needed on aspects of fertilizer penetration in the leaf (Haytova, 2013), rates and time of application.

In view of the above, for test the hypothesis that dwarf cashew seedlings respond to foliar fertilizer application and have superior quality, the objective of this study was to evaluate the effects of foliar fertilizer rates and time of application on 'BRS 226' dwarf cashew seedlings after grafting.

\section{MATERIAL AND METHODS}

The study was carried out in the seedling production nursery of the Experimental Field of Embrapa Tropical Agroindustry, located in the municipality of Pacajus, Ceará, Brazil ( $4^{\circ} 11^{\prime} 12^{\prime}$ 'S; $38^{\circ} 30^{\prime} 01^{\prime}$ W; average altitude of $79 \mathrm{~m}$ ). The predominant climate in the region is hot and sub-humid, with annual averages of precipitation and temperatures of $918 \mathrm{~mm}$ and $26.5^{\circ} \mathrm{C}$, respectively (Serrano et al., 2017).

The experiment was carried out in a completely randomized design, with five treatments and 24 replicates: $\mathrm{T}_{0}$ : control (without fertilization); $\mathrm{T}_{1}$ - Foliar fertilizer at 45 days after grafting (DAG) $(50 \%$ of the recommended rate) + at $60 \mathrm{DAG}(50 \%$ of the recommended rate); $\mathrm{T}_{2}$-Foliar fertilizer at $60 \mathrm{DAG}$ (recommended rate); $\mathrm{T}_{3}$ - Foliar fertilizer at $45 \mathrm{DAG}$ (recommended rate) + at $60 \mathrm{DAG}$ (recommended rate); $\mathrm{T}_{4}$ - Foliar fertilizer at 80 DAG (recommended rate). The commercial product Greenleaf $^{\circledR}$ was used at the recommended rate for fruit crops in general, $2.5 \mathrm{~g} \mathrm{~L}^{-1}$, with following composition guaranteed by the manufacturer: $20 \% \mathrm{~N} ; 20 \% \mathrm{P}_{2} \mathrm{O}_{5} ; 20 \%$ $\mathrm{K}_{2} \mathrm{O} ; 0.1 \% \mathrm{~B} ; 0.05 \% \mathrm{Cu} ; 0.2 \% \mathrm{Fe} ; 0.1 \% \mathrm{Zn}$ and $1.32 \%$ EDTA. Foliar fertilization was applied using a backpack sprayer with a capacity of $5 \mathrm{~L}$.

The experimental unit consisted of one plant, coming from nut-seed of the dwarf-cashew clone ' $\mathrm{CCP}$ 06'. Plastic tubes with volumetric capacity of $288 \mathrm{~mL}$ were previously filled with substrate consisting of vermiculite, dried and shredded carnauba bagana (leaf fibers after wax extraction) and hydromorphic soil, in the proportion of $2: 1: 1$. Then, the tubes were placed on trays, suspended from the soil, under conditions of full sunlight.

Plants of the rootstock 'CCP 06' were grafted at 60 days after sowing by means of side grafting (Serrano; Cavalcanti Junior, 2016), with scion of the clone 'BRS 226'. After grafting, the seedlings were kept in a screened nursery for 45 days and, after this period, they were transferred to beds under full sun.

The leaves were sprayed on both the adaxial and the abaxial sides, and the procedure was interrupted when the solution containing the foliar fertilizer ran off. The 
volumes of solution applied per tray were equal to $250 \mathrm{~mL}$ at $45 \mathrm{DAG}$ and to $390 \mathrm{~mL}$ at 60 and $80 \mathrm{DAG}$, and both applications of the solution contained the rate recommended by the manufacturer $\left(2.5 \mathrm{~g} \mathrm{~L}^{-1}\right)$, except for the treatment $\mathrm{T}_{1}$, which contained half of the recommended rate $\left(1.25 \mathrm{~g} \mathrm{~L}^{-1}\right)$. To avoid the washing of the leaves, no sprinkler irrigation was performed and plants were protected from the rains in the 48 hours after foliar fertilizer application.

At 190 days after sowing (DAS), equivalent to 130 DAG, plants were evaluated for height, stem diameter and number of leaves. Plant height was determined using a tape measure, from the collar to the apex, while stem diameter was measured with a digital caliper at $5 \mathrm{~cm}$ from the collar (grafting point). Subsequently, the plants were harvested and separated into shoots and roots, which were washed and dried in an oven at $65^{\circ} \mathrm{C}$ until constant weight. After drying, the dry masses of leaves, stem, shoots (leaves + stem), roots and total (shoots + roots) were determined.

Leaf samples were ground in a Wiley-type mill and subsequently subjected to sulfuric digestion for determining $\mathrm{N}$ content and to nitric-perchloric digestion for determining $\mathrm{P}, \mathrm{K}, \mathrm{Ca}, \mathrm{Mg}, \mathrm{S}, \mathrm{Cu}, \mathrm{Fe}, \mathrm{Mn}$ and $\mathrm{Zn}$ contents. For $\mathrm{B}$ determination, plant tissue was incinerated in a muffle. The entire methodology is described in Miyazawa et al. (2009).

The data obtained were subjected to analysis of variance and the means were compared by Scott-Knott test at $5 \%$ probability level, using the statistical program Sisvar $^{\circledR}$ (Ferreira, 2011).

\section{RESULTS AND DISCUSSION}

At 130 days after grafting (equivalent to 190 days after sowing), there was no significant effect of the foliar fertilizer rates and time of application on the height and number of leaves of grafted seedlings of 'BRS 226' cashew. The average values obtained for plant height and number of leaves were $20.15 \mathrm{~cm}$ and 5.38 leaves, respectively (Table 1).

Foliar fertilizer application at $80 \mathrm{DAG}$ using the recommended rate $\left(2.5 \mathrm{~g} \mathrm{~L}^{-1}\right)$ did not influence the stem diameter of 'BRS 226' grafted dwarf-cashew seedlings, compared to the treatment without fertilization (Table 1). For the other treatments, applied at 45 and 60 DAG, with $50 \%$ and $100 \%$ of the recommended rate of foliar fertilizer, there was a reduction in stem diameter in comparison to unfertilized plants. Unlike plant height and number of leaves, the stem diameter of cashew seedlings proved to be sensitive to the fertilization management used. In cocoa (Theobroma cacao) seedlings, Souza Júnior and Carmelo (2008) found a $13 \%$ reduction in stem diameter with the application of urea through the leaves, in comparison to the supply via substrate.

Table 1: Plant height $(\mathrm{PH})$, stem diameter (SD) and number of leaves (NL) of grafted seedlings of 'BRS 226' cashew, 190 days after sowing, as a function of foliar fertilizer (NPK 20-20-20) rates and time of application ${ }^{(1)}$.

\begin{tabular}{cccc}
\hline Treatments & PH & SD & NL \\
\hline & $----\mathrm{cm}$--- & $---\mathrm{mm}---$ & \\
Control & $19.85 \mathrm{a}$ & $6.61 \mathrm{a}$ & $5.20 \mathrm{a}$ \\
45 DAG 50\%+60 & $20.20 \mathrm{a}$ & $6.09 \mathrm{~b}$ & $5.50 \mathrm{a}$ \\
DAG 50\% & & & \\
60 DAG 100\% & $19.95 \mathrm{a}$ & $6.27 \mathrm{~b}$ & $5.50 \mathrm{a}$ \\
45 DAG 100\%+60 & $20.45 \mathrm{a}$ & $6.05 \mathrm{~b}$ & $5.35 \mathrm{a}$ \\
DAG100\% & & & \\
80 DAG 100\% & $20.30 \mathrm{a}$ & $6.90 \mathrm{a}$ & $5.35 \mathrm{a}$ \\
\hline Means & 20.15 & 6.38 & 5.38 \\
CV (\%) & 5.89 & 14.64 & 18.32 \\
\hline
\end{tabular}

(1)Means followed by the same letter in the columns do not differ by Scott-Knott test at $5 \%$ probability level. 45 DAG $50 \%+60$ DAG 50\%: foliar fertilizer at 45 days +60 days after grafting at the concentration of $50 \%$ of the recommended rate; 60 DAG 100\%: foliar fertilizer at 60 days after grafting at the recommended rate; 45 DAG 100\% + 60 DAG 100\%: foliar fertilizer at 45 days +60 days after grafting at the recommended rate; 80 DAG 100\%: foliar fertilizer at 80 days after grafting at the recommended rate.

Except for the treatment in which the foliar fertilizer was applied at 45 and $60 \mathrm{DAG}$, using the recommended rate, the others caused an increase in the leaf dry mass of cashew seedlings, compared to unfertilized plants (Table 2). Foliar fertilizer application at the recommended rate $\left(2.5 \mathrm{~g} \mathrm{~L}^{-1}\right)$ at 45 and $60 \mathrm{DAG}$, especially at the first time, may have inhibited the growth of newly produced leaves, without the manifestation of symptoms of toxicity, which may justify the lower leaf dry mass production in comparison to the other treatments that received foliar fertilization. The application of high rates of foliar fertilizers can reduce the rate of foliar absorption (Stiegler; Richardson; Karcher, 2011). This possibility is reinforced by observing the treatment in which half of the recommended rate was applied at 45 and 60 DAG, but that led to the highest leaf dry mass production ( $38 \%$ increase compared to unfertilized plants). It is worth pointing out that the total dry mass is one of the most important variables in the evaluation of seedling quality (Binotto; Lúcio; Lopes, 2010; Eloy et al., 2013; Melo et 
al., 2018), being a good indicator of the seedlings' capacity of resistance to environmental adversities.

Despite the negative influence of foliar fertilizer application on stem diameter (Table 1), the dry mass accumulation in this organ was not influenced by the fertilization management in 'BRS 226' grafted dwarfcashew seedlings.

Foliar fertilizer application at 45 and 60 DAG, using the recommended rate, reduced the shoot dry mass of 'BRS 226' cashew seedlings (Table 2), in comparison to unfertilized plants, which may be directly related to the previously mentioned lower accumulation of leaf dry mass.

Root dry mass increased with the application of foliar fertilizer at 45 and $60 \mathrm{DAG}$, with $50 \%$ of the recommended rate, and at $80 \mathrm{DAG}$, with the rate recommended by the fertilizer manufacturer. Foliar fertilization can stimulate the capacity of the root system to absorb nutrients from the soil solution, favoring greater development. The treatments that led to higher leaf and root dry masses promoted 'BRS 226' grafted dwarfcashew seedlings with higher total dry mass accumulation. Foliar fertilizer application at 45 and $60 \mathrm{DAG}$, using $50 \%$ of the recommended rate, and at $80 \mathrm{DAG}$, using the recommended rate $(100 \%)$, promoted increments of $9 \%$ and $13 \%$ in the total dry mass, respectively, in comparison to unfertilized plants. Foliar fertilizer application in a single rate for the production of 'BRS 226' dwarf cashew seedlings may be advantageous as it reduces the costs with labor. Single application of low rates of B or $\mathrm{Zn}$ nano-fertilizer increased the yield of pomegranate (Punica granatum L.) fruits (Davarpanah et al., 2016). In addition to the costs with labor, some crops positively respond to the application of the single rate of foliar fertilizer.

Regarding leaf nutrient content, foliar fertilization did not influence the contents of $\mathrm{N}, \mathrm{K}, \mathrm{Ca}, \mathrm{S}, \mathrm{Cu}$ and $\mathrm{Fe}$, but the application of the fertilizer at 45 and $60 \mathrm{DAG}$, at the concentration of $50 \%$ of the rate, reduced $\mathrm{P}, \mathrm{Mg}, \mathrm{Mn}$, $\mathrm{Zn}$ and $\mathrm{B}$ contents in the leaves of 'BRS 226' grafted dwarf cashew seedlings (Tables 3 and 4 ). This decrease in nutrient contents can be explained by the effect of dilution of nutrients in leaves, due to the higher production of total dry mass by the plants (Table 2).

In camu-camu (Myrciaria dubia (H.B.K.) McVaugh) plants, foliar fertilization $(200 \mathrm{~mL}$ per plant with $0.16 \mathrm{~g}$ of $\mathrm{N} ; 0.18 \mathrm{~g}$ of $\mathrm{P}_{2} \mathrm{O}_{5} ; 0.18 \mathrm{~g}$ of $\mathrm{K}_{2} \mathrm{O} ; 0.02$ $\mathrm{g}$ de $\mathrm{Ca} ; 0.02 \mathrm{~g}$ of $\mathrm{Cl} ; 0.02 \mathrm{~g}$ of S; $0.02 \mathrm{~g}$ of Fe; $0.01 \mathrm{~g}$ of $\mathrm{Cu} ; 0.01 \mathrm{~g}$ of $\mathrm{Zn} ; 0.004 \mathrm{~g}$ of $\mathrm{Mn} ; 0.0001 \mathrm{~g}$ of Co and $0.0001 \mathrm{~g}$ of Mo) increased the contents of $\mathrm{Fe}, \mathrm{Zn}$ and $\mathrm{P}$ in the leaves, compared to the treatments tested (Esashika; Oliveira; Moreira, 2011). Foliar fertilization affected only the contents of $\mathrm{S}$ in the shoots of papaya (Carica papaya L.) seedlings, and the other nutrients (N, P, K, Ca and $\mathrm{Mg}$ ) were supplied through the organic substrates studied (Albano et al., 2017). According to meta-analysis studies, foliar fertilization with a specific nutrient caused an increase in the leaf content of this nutrient, but studies on its interactions are needed (Ostertag; Dimanno, 2016). The response of the crop to foliar fertilization may be variable due to lack of knowledge about the factors associated with fertilizer penetration in the leaf (Haytova, 2013).

Table 2: Leaf (LDM), stem (StDM), shoot (ShDM), root (RDM) and total (TDM) dry mass production of grafted seedlings of 'BRS 226' cashew, at 190 days after sowing, as a function of foliar fertilizer (NPK 20-20-20) rates and time of application ${ }^{(1)}$.

\begin{tabular}{|c|c|c|c|c|c|}
\hline Treatments & LDM & StDM & ShDM & RDM & TDM \\
\hline & \multicolumn{5}{|c|}{------------------------- g per plant------------------------- } \\
\hline Control & $0.58 c$ & $2.86 a$ & $3.44 a$ & $1.45 b$ & $4.89 \mathrm{~b}$ \\
\hline 45 DAG 50\% + 60 DAG 50\% & $0.80 a$ & $2.72 a$ & $3.52 a$ & $1.78 a$ & $5.31 a$ \\
\hline 60 DAG 100\% & $0.67 b$ & $2.64 a$ & $3.32 \mathrm{a}$ & $1.37 b$ & $4.70 \mathrm{~b}$ \\
\hline 45 DAG $100 \%+60$ DAG $100 \%$ & $0.53 c$ & $2.46 a$ & $2.99 \mathrm{~b}$ & $1.24 b$ & $4.24 \mathrm{c}$ \\
\hline 80 DAG $100 \%$ & $0.68 \mathrm{~b}$ & 3.09a & $3.78 a$ & $1.76 a$ & $5.54 a$ \\
\hline Means & 0.65 & 2.75 & 3.41 & 1.52 & 4.94 \\
\hline CV (\%) & 28.08 & 23.39 & 21.62 & 28.87 & 17.34 \\
\hline
\end{tabular}

(1)Means followed by the same letter in the columns do not differ by Scott-Knott test at 5\% probability level. 45 DAG $50 \%+60$ DAG 50\%: foliar fertilizer at 45 days +60 days after grafting at the concentration of 50\% of the recommended rate; 60 DAG $100 \%$ : foliar fertilizer at 60 days after grafting at the recommended rate; 45 DAG 100\% + 60 DAG 100\%: foliar fertilizer at 45 days + 60 days after grafting at the recommended rate; 80 DAG 100\%: foliar fertilizer at 80 days after grafting at the recommended rate. 
Table 3: Contents of macronutrients in leaves of grafted seedlings of 'BRS 226 ' cashew, at 190 days after sowing, as a function of foliar fertilizer (NPK 20-20-20) rates and time of application (1).

\begin{tabular}{|c|c|c|c|c|c|c|}
\hline Treatments & $\mathrm{N}$ & $\mathrm{P}$ & K & $\mathrm{Ca}$ & $\mathrm{Mg}$ & $S$ \\
\hline \multicolumn{7}{|c|}{---------------------- g kg-1 ----------------- } \\
\hline Control & $9.7 a$ & $1.3 a$ & $14.7 a$ & $3.9 a$ & $3.7 a$ & $0.6 a$ \\
\hline 45 DAG 50\% + 60 DAG 50\% & $9.9 a$ & $1.0 \mathrm{~b}$ & $16.0 \mathrm{a}$ & $3.5 a$ & $3.0 b$ & $0.6 a$ \\
\hline 60 DAG 100\% & $9.9 a$ & $1.5 a$ & $17.1 \mathrm{a}$ & $3.6 a$ & $3.6 a$ & $0.6 a$ \\
\hline 45 DAG $100 \%+60$ DAG $100 \%$ & $10.5 a$ & $1.6 a$ & $16.2 \mathrm{a}$ & $3.8 a$ & $3.8 a$ & $0.6 a$ \\
\hline 80 DAG $100 \%$ & $9.8 a$ & $1.3 a$ & $15.2 \mathrm{a}$ & $3.9 a$ & $3.6 a$ & $0.6 a$ \\
\hline CV (\%) & 7.66 & 21.21 & 14.03 & 14.44 & 13.82 & 23.03 \\
\hline
\end{tabular}

(1) Means followed by the same letter in the columns do not differ by Scott-Knott test at 5\% probability level. 45 DAG 50\% + 60 DAG 50\%: foliar fertilizer at 45 days + 60 days after grafting at the concentration of 50\% of the recommended rate; 60 DAG 100\%: foliar fertilizer at 60 days after grafting at the recommended rate; 45 DAG 100\% + 60 DAG 100\%: foliar fertilizer at 45 days +60 days after grafting at the recommended rate; 80 DAG 100\%: foliar fertilizer at 80 days after grafting at the recommended rate.

Table 4: Contents of micronutrients in leaves of grafted seedlings of 'BRS 226' cashew, at 190 days after sowing, as a function of foliar fertilizer (NPK 20-20-20) rates and time of application ${ }^{(1)}$.

\begin{tabular}{|c|c|c|c|c|c|}
\hline Treatments & $\mathrm{Cu}$ & $\mathrm{Fe}$ & $\mathrm{Zn}$ & $\mathrm{Mn}$ & $\mathrm{B}$ \\
\hline & \multicolumn{5}{|c|}{ 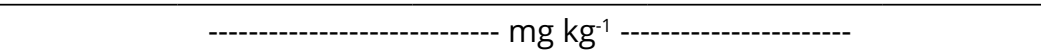 } \\
\hline Control & $77 a$ & $74 a$ & $16 a$ & $187 a$ & $11 b$ \\
\hline 45 DAG 50\% + 60 DAG 50\% & $83 a$ & $35 a$ & $9 b$ & $148 b$ & $10 b$ \\
\hline 60 DAG $100 \%$ & $105 a$ & $37 a$ & $14 a$ & $137 b$ & $9 b$ \\
\hline 45 DAG $100 \%+60$ DAG $100 \%$ & $83 a$ & $56 a$ & $13 a$ & $175 a$ & $14 a$ \\
\hline 80 DAG $100 \%$ & $72 a$ & $48 a$ & $13 a$ & $210 a$ & $14 a$ \\
\hline CV (\%) & 28.75 & 27.40 & 24.38 & 16.85 & 24.30 \\
\hline
\end{tabular}

(1) Means followed by the same letter in the columns do not differ by Scott-Knott test at 5\% probability level. 45 DAG $50 \%$ + 60 DAG 50\%: foliar fertilizer at 45 days +60 days after grafting at the concentration of $50 \%$ of the recommended rate; 60 DAG 100\%: foliar fertilizer at 60 days after grafting at the recommended rate; 45 DAG 100\% + 60 DAG 100\%: foliar fertilizer at 45 days +60 days after grafting at the recommended rate; 80 DAG 100\%: foliar fertilizer at 80 days after grafting at the recommended rate.

These examples illustrate the diversity of fruit trees response to foliar fertilizer application. To improve the efficacy and use of these fertilizers, factors that interfere with the absorption, translocation and utilization of nutrients by plants should be considered.

There was a significant difference in the $B$ contents with foliar fertilizer applications at 45 and 60 DAG, using the recommended rate, and at $80 \mathrm{DAG}$, using the recommended rate, in comparison to unfertilized plants (Table 4). This result can be justified by the low mobility of $B$ in the phloem, because its translocation from the leaves to other organs is virtually zero (Tomaz et al., 2013). For cashew seedlings, it was observed that with the foliar application of B and fertilization with B in the substrate, this element via substrate was absorbed and translocated to young leaves, suggesting that there may be mechanisms to justify the mobility of B in the phloem (Canesin; Buzetti; Souza, 2015).

The possible explanation for the lower contents of $\mathrm{Zn}$ and $\mathrm{Mn}$ found in the treatments mentioned above is the possible retention of nutrients by leaf cuticle. To avoid water loss, the cashew tree has a very thick leaf cuticle, which may have contributed to the retention of these elements when the fertilizer was applied through the leaves (Malavolta, 2006; Ramos; Cotta; Fonseca Filho, 2016).

The leaf contents of $\mathrm{N}, \mathrm{K}, \mathrm{Mg}, \mathrm{S}, \mathrm{Cu}, \mathrm{Fe}$ and $\mathrm{Zn}$ determined in the 'BRS 226' grafted dwarf-cashew seedlings are below the contents found by Serrano et al. 
(2017) in seedlings of the same clone with the application of controlled-release fertilizer (NPK 13-06-16). On the other hand, the leaf contents of $\mathrm{Ca}, \mathrm{Mn}$ and $\mathrm{B}$ were higher. The differences found in the nutrient contents in this study, in comparison to those reported by Serrano et al. (2017), are possibly due to the difference nutrient composition of the fertilizers, forms of application, and absorption and mobility of nutrients. It is known that the process of nutrient absorption by leaves differs from that of the roots, because the leaf cell walls are covered by a cuticle, which is not found in the root structure (Fageria et al., 2009). Variations in nutrient contents in the leaves can, regardless of the mobility, be related to the action of hormones that, by stimuli, displace the nutrients towards the sink organ (Taiz et al., 2017).

It was verified that the foliar fertilizer applied after grafting promoted alterations in the development of 'BRS 226' seedlings; however, more effective results were conditioned on the rate and time of application. Foliar fertilization at 45 and $60 \mathrm{DAG}$, with $50 \%$ of the recommended rate $\left(1.25 \mathrm{~g} \mathrm{~L}^{-1}\right)$, promoted an increase in the dry masses of leaves, shoots, roots and total, compared to that applied at the same time, but at the recommended rate. It is worth remembering that the foliar fertilizer rate of $100 \%\left(2.5 \mathrm{~g} \mathrm{~L}^{-1}\right)$ is indicated for fruit crops in general, and this negative effect of the application of the recommended rate may be justified by the higher concentration of the nutrients present in the fertilizer, above the levels required by the cashew tree, since research studies have shown that this fruit crop needs lower quantities of nutrients, compared to other species.

The time of application of foliar fertilizer can influence the responses of crops. According to Fageria et al. (2009), foliar fertilization in food crops may not increase yield, but can raise the protein content of their grains, if applied during anthesis or flowering. According to the same authors, in rice crop, foliar spraying of nutrients should not be carried out after flowering, as it may cause panicle discoloration.

$\mathrm{Bi}$ and Scagel (2007) recommend foliar N application during the seedling production stage in the nursery, since the deficiency of this element in the early stages can be corrected, besides reducing the total amount needed and reducing $\mathrm{N}$ runoff.

Besides the application of foliar fertilizer at 45 and 60 DAG with $50 \%$ of the recommended rate, treatment at $80 \mathrm{DAG}$ with the recommended rate also led to positive results, with increments in leaf, root and total dry masses compared to the unfertilized treatment. The positive response of grafted 'BRS 226' cashew seedlings to foliar fertilizer application may be due to the greater development of leaves and higher nutritional requirement of plants in this period, which allowed better utilization of the nutrients applied. The efficiency of nutrient absorption by the leaves depends mainly on leaf area (which varies with developmental stage) and on the number of stomata and trichomes (Smoleń, 2012).

In a comparison of the managements that promoted 'BRS 226' grafted dwarf-cashew seedlings with greater development, i.e., that responded to foliar fertilizer application at 45 and $60 \mathrm{DAG}$, with $50 \%$ of the recommended rate, and at $80 \mathrm{DAG}$, with the recommended rate, the latter has as an advantage the single fertilizer application throughout the seedling production process, which represents savings, at least in the number of applications.

\section{CONCLUSIONS}

In the production of grafted seedlings of 'BRS 226' dwarf-cashew, it's recommended to foliar fertilization at 45 and 60 days after grafting, with $1.25 \mathrm{~g} \mathrm{~L}^{-1}$ of the product based on NPK 20-20-20; or a single dose application of $2.5 \mathrm{~g} \mathrm{~L}^{-1}$ at 80 days after grafting.

\section{REFERENCES}

ALBANO, F. G. et al. New substrate containing agroindustrial carnauba residue for production of papaya under foliar fertilization. Revista Brasileira de Engenharia Agrícola e Ambiental, 21(2):128-133, 2017.

BI, G.; SCAGEL, C. Nitrogen foliar feeding has advantages. Nursery Management and Production, 2007. p.43-46.

BINOTTO, A. F.; LÚCIO, A. D. C.; LOPES, S. J. Correlations between variables and the dickson quality index in forest seedlings. Cerne, 16(4):457-464, 2010.

CANESIN, R. C. S. F.; BUZETTI, S.; SOUZA, J. A. Redistribution of ${ }^{10} \mathrm{~B}$ absorbed by leaves and roots of cashew seedlings. Journal of Plant Nutrition, 38(4):639-646, 2015.

CAVALCANTi JÚNIOR, A. T. O que plantar. In: ARAÚJO, J. P. P. (Ed.). Agronegócio caju: Práticas e inovações. Brasília: EMBRAPA, 2013. p.61-75.

DAVARPANAH, S. et al. Effects of foliar applications of zinc and boron nano-fertilizers on pomegranate (Punica granatum CV. Ardestani) fruit yield and quality. Scientia Horticulturae, 210(1):57-64, 2016.

ELOY, E. et al. Avaliação da qualidade de mudas de Eucalyptus grandis utilizando parâmetros morfológicos. Floresta, 43(3):373-384, 2013. 
ESASHIKA, T.; OLIVEIRA, L. A.; MOREIRA, F. W. Teores foliares de nutrientes em plantas de camucamuzeiro (Myrciaria dubia (H.B.K.) McVaugh) submetidas a adubações orgânica, mineral e foliar. Revista Brasileira de Ciências Agrárias, 6(3):391-400, 2011.

FAGERIA, N. K. et al. Foliar fertilization of crop plants. Journal of Plant Nutrition, 32(6):1044-1064, 2009.

FERNÁNDEZ, V.; EICHERT, T. Uptake of hydrophilic solutes through plant leaves: Current state of knowledge and perspectives of foliar fertilization. Critical Reviews in Plant Sciences, 28(1/2): 36-68, 2009.

FERNÁNDEZ, V.; SOTIROPOULOS, T.; BROWN, P. H. Foliar fertilization: scientific principles and field practices. (1 ${ }^{\text {st }}$ Ed.). Paris: International Fertilizer Industry Association (IFA), 2013. Available in: <https://www.fertilizer.org/images/ Library_Downloads/2013_foliar_fertilization_HR.pdf>. Access in: October, 21, 2019.

FERREIRA, D. F. Sisvar: A computer statistical analysis system. Ciência e Agrotecnologia, 35(6):1039-1042, 2011.

HAYTOVA, D. A review of foliar fertilization of some vegetables crops. Annual Review and Research in Biology, 3(4):455465, 2013.

KOSTADINOV, K.; KOSTADINOVA, S. Nitrogen efficiency in eggplants (Solanum melongena $L$.) depending on fertilizing. Bulgarian Journal of Agricultural Science, 20(2):287-292, 2014.

MALAVOLTA, E. Manual de nutrição mineral de plantas. São Paulo: Editora Agronômica Ceres, 2006. 638p.

MELO, L. A et al. Qualidade e crescimento inicial de mudas de Mimosa caesalpiniifolia Benth. produzidas em diferentes volumes de recipientes. Ciência Florestal, 28(1):47-55, 2018.

MESQUITA, J. B. R. et al. Efeito da compatibilidade entre porta-enxerto vs enxerto de cajueiro comum em viveiro. Agropecuária Técnica, 31(1): 9-57, 2010.

MIYAZAWA, M. et al. Análise química de tecido vegetal. In: SILVA, F.C. (Ed.). Manual de análises químicas de solos, plantas e fertilizantes. 2. ed. rev. e ampl. Brasília: (s.n.), 2009. p.191-234.

OSTERTAG, R.; DIMANNO, N. M. Detecting terrestrial nutrient limitation: A global meta-analysis of foliar nutrient concentrations after fertilization. Frontiers in Earth Science, 4(23):1-14, 2016.

PATIL, B.; CHETAN, H.T. Foliar fertilization of nutrients. Marumegh, 3(1):49-53, 2018.

RAMOS, G. Q.; COTTA, E. A.; FONSECA FILHO, H. D. Análise morfológica das folhas de Anacardium occidentale L. Biota Amazônia, 6(1):16-19, 2016.

SERRANO, L. A. L. et al. Adubo de liberação lenta (NPK 1306-16) na produção de mudas de cajueiro-anão em citrovasos. Fortaleza: Embrapa Agroindústria Tropical, 2017. 26p.

SERRANO, L. A. L.; CAVALCANTI JUNIOR, A. T. Produção de mudas de cajueiro. In: SERRANO, L. A. L. (Org.). Sistema de Produção do Caju. 2ed. Brasília-DF: Embrapa Informação Tecnológica, 1: 43-54, 2016.

SMOLEŃ, S. Foliar Nutrition: Current state of knowledge and opportunities. In: SRIVASTAVA, A. (Eds) Advances in Citrus Nutrition. Springer: Dordrecht, 2012, p.41-58.

SOUZA JÚNIOR, J. O.; CARMELLO, Q. A. C. Formas de adubação e doses de ureia para mudas clonais de cacau cultivadas em substratos. Revista Brasileira de Ciência do Solo, 32(6): 2367-2374, 2008.

STIEGLER, J. C.; RICHARDSON, M. D.; KARCHER, D. E. Foliar nitrogen uptake following urea application to putting green turfgrass species. Crop Science, 51(3):1253-1260, 2011.

SULLIVAN, B.W. et al. Assessing nutrient limitation in complex forested ecosystems: Alternatives to large-scale fertilization experiments. Ecology, 95(3):668-681, 2014.

TAIZ, L. et al. Fisiologia e desenvolvimento vegetal. 6. ed. Porto Alegre: Artmed, 2017. 888p.

TOMAZ, M. A. et al. Tópicos especiais em produção vegetal IV. Espírito Santo: Editora CAUFES, 2013. 694p. 